\title{
Regulation of proBACE1 by Glycosaminoglycans
}

\author{
David H. Small David W. Klaver Marie Beckman \\ Department of Biochemistry and Molecular Biology, Monash University, Clayton, Vic., and \\ Menzies Research Institute, University of Tasmania, Hobart, Tas., Australia
}

\section{Key Words}

$\beta$-Secretase - Glycosaminoglycan - Heparin - Proteolysis · Amyloid processing $\cdot \beta$-Amyloid

\begin{abstract}
The $\beta$-secretase (BACE1) is initially synthesized as a partially active zymogen containing a prodomain which can be further activated through proteolytic cleavage of the prodomain by a furin-like protease. The active site of BACE1 is large and although a number of high-affinity active-site inhibitors of BACE1 have been described, most of these compounds are large, polar and do not cross the blood-brain barrier. However, it may be possible to target other regions of the protein which regulate BACE1 allosterically. We have found that proBACE1 can be stimulated by relatively low concentrations (e.g. $1 \mu \mathrm{g} / \mathrm{ml}$ ) of heparin. Heparin initially increases proBACE1 activity, probably by binding to the prodomain, which decreases steric inhibition at the active site. However, the heparin-activated zymogen also undergoes autocatalysis, which ultimately leads to a loss of enzyme activity. We speculate that proBACE1 can be regulated by endogenous heparan sulfate proteoglycans and that drugs which target this interaction may have value in the treatment of Alzheimer's disease.

Copyright @ 2008 S. Karger AG, Basel
\end{abstract}

The $\beta$-secretase (BACE1) is an important target for Alzheimer's disease (AD) drug development because the enzyme catalyzes the first step in the production of $\beta$ amyloid, and because the enzyme may have only a limited range of substrates in vivo [1]. BACE1 belongs to the family of aspartic proteases, but it differs from many family members by being membrane anchored. Fulllength BACE1 contains 501 amino-acid residues including a signal peptide sequence and a 24 -residue prodomain. During its maturation in the secretory pathway, BACE1 undergoes complex N-linked glycosylation [2]. Evidence suggests that proBACE1 becomes fully glycosylated first and then the prodomain, which is important for the proper folding of the protease domain, is removed by a furin-like protease, possibly in the trans-Golgi network (TGN) [3]. However, the exact subcellular compartments in which the prodomain is cleaved off have not yet been established. Unlike many aspartic proteases, the prodomain does not completely suppress activity of the enzyme [4]. Therefore, proBACE1 may have an enzymic function in vivo.

BACE1 may be a suitable target for drug development because BACE1 knockout mice are viable [5]. Apart from a hypomyelination phenotype, caused by the fact that neuregulin 1 (a BACE1 substrate) is important for oligodendrocyte development [6], BACE1 knockout mice have no major neuropathological abnormalities. However, the development of drugs which inhibit BACE1 at the active site has been difficult. The active site of BACE1 is large

Prof. David H. Smal

Menzies Research Institute, University of Tasmania

Private Bag 23, Hobart TAS 7001 (Australia)

Tel. +61 362267700 , Fax +61 362267704 , E-Mail d.h.small@menzies.utas.edu.au 
Fig. 1. Model of the activation of proBACE1 by heparin. ProBACE1 has a lower enzymic activity than mature BACE1. The binding of heparin to a cluster of positively charged residues in the prodomain results in a conformational shift which relieves steric hindrance by the prodomain at the active site.

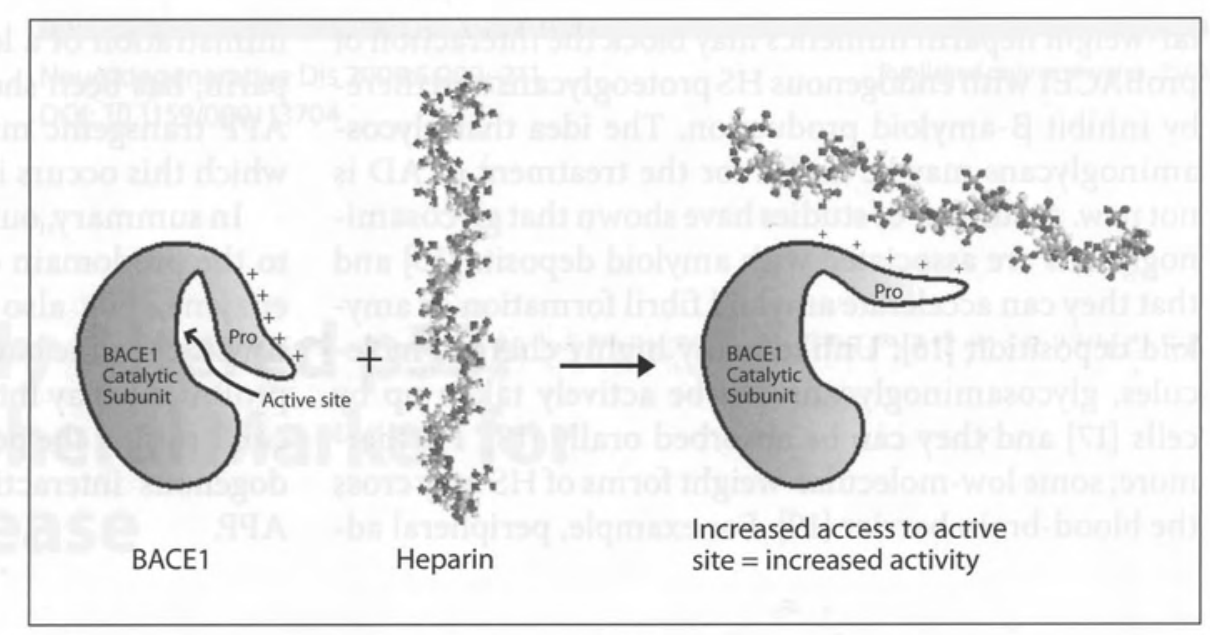

and many drugs which inhibit the protease by binding to the active site are large and cross the blood-brain barrier poorly [7]. For this reason, the identification of low-molecular-weight BACE1 inhibitors is of considerable importance.

\section{BACE1 Is a Heparin-Binding Protein}

Scholefield et al. [8] first reported that BACE1 can bind to and be inhibited by heparin and that it can be coimmunoprecipitated with heparan sulfate (HS) proteoglycans. HS is a sulfated glycosaminoglycan commonly attached to various core proteins via an O-linked tetrasaccharide of xylose-galactose-galactose-glucuronic acid [9]. Heparin is a highly sulfated form of HS. As a number of proteases are known to be regulated by HS binding, the result of Scholefield et al. [8] suggests that BACE1 may also be regulated by HS in vivo.

Our studies show that heparin's effects on BACE1 are complex [10]. High concentrations of heparin $(100 \mu \mathrm{g} /$ $\mathrm{ml}$ ) inhibit the enzyme, whereas lower concentrations $(1 \mu \mathrm{g} / \mathrm{ml})$ stimulate activity. The stimulatory effect requires the presence of the prodomain and our data support the view that heparin can bind directly to the prodomain. For example, a peptide homologous to the prodomain was found to bind to heparin and our studies show that mature (prodomain cleaved) BACE1 cannot be activated by heparin. It seems likely that the binding of heparin to the prodomain activates the enzyme by removing steric hindrance at the active site (fig. 1).

Low concentrations $(1 \mu \mathrm{g} / \mathrm{ml})$ of heparin were also found to stimulate autocatalytic cleavage of proBACE1
[10]. The amount of autocatalytic cleavage correlates with inactivation of the enzyme that can be observed at longer time periods of incubation. Analysis of the products of cleavage by tandem mass spectrometry revealed that one of the heparin-stimulated autocatalytic cleavage sites was at phenylalanine-99, close to one of the active-site aspartate residues (aspartate-93) which are critical for enzyme activity. It is possible that cleavage at this position (or at another position close to the active site) may account for the loss of enzyme activity.

\section{Can Glycosaminoglycans Be Used for the Treatment of $A D$ ?}

Assembly of HS proteoglycans is known to begin in the lumen of the endoplasmic reticulum, and the final stages of this assembly (sulfation) occur in the TGN [11]. ProBACE1 is also synthesized in the endoplasmic reticulum and processed through the Golgi apparatus. Removal of the prodomain of BACE1 by furin is likely to occur in the TGN or in later membrane compartments [12]. Therefore, as $\beta$-secretase processing of amyloid precursor protein (APP) can occur in compartments where enzymatically active proBACE1 may reside, such as the endoplasmic reticulum and the TGN [13], it may be hypothesized that proBACE1 has a direct role in APP processing. Furthermore, as HS proteoglycans are likely to be in the same compartments as proBACE1, they may help to regulate proBACE1 cleavage of APP.

Leveugle et al. [14] found that exogenously added heparin can stimulate $\beta$-secretase cleavage of APP in cell culture. This finding raises the possibility that low-molecu- 
lar-weight heparin mimetics may block the interaction of proBACE1 with endogenous HS proteoglycans and thereby inhibit $\beta$-amyloid production. The idea that glycosaminoglycans may be useful for the treatment of $\mathrm{AD}$ is not new. A number of studies have shown that glycosaminoglycans are associated with amyloid deposits [15] and that they can accelerate amyloid fibril formation or amyloid deposition [16]. Unlike many highly charged molecules, glycosaminoglycans can be actively taken up by cells [17] and they can be absorbed orally [18]. Furthermore, some low-molecular-weight forms of HS may cross the blood-brain barrier [19]. For example, peripheral ad- ministration of a low-molecular-weight heparin, enoxaparin, has been shown to reduce the amyloid burden in APP transgenic mice [20], although the mechanism by which this occurs is unclear.

In summary, our work indicates that heparin can bind to the prodomain of BACE1. This binding activates the enzyme, but also increases autocatalytic cleavage of BACE1. On the basis of these findings, we speculate that proBACE1 may interact with endogenous HS proteoglycans, raising the possibility that interfering with this endogenous interaction may disrupt BACE1 cleavage of APP.

\section{References}

1 Vassar R: $\beta$-Secretase (BACE) as a drug target for Alzheimer's disease. Adv Drug Deliv Rev 2002;54:1589-1602.

2 Sidera C, Parsons R, Austen B: Post-translational processing of $\beta$-secretase in Alzheimer's disease. Proteomics 2005;5:15331543.

3 Bennett BD, Denis P, Haniu M, Teplow DB, Kahn S, Louis JC, Citron M, Vassar R: A furin-like convertase mediates propeptide cleavage of BACE, the Alzheimer's $\beta$-secretase. J Biol Chem 2000;275:37712-37717.

4 Shi XP, Chen E, Yin KC, Na S, Garsky VM, Lai MT, Li YM, Platchek M, Register RB, Sardana MK, Tang MJ, Thiebeau J, Wood T, Shafer JA, Gardell SJ: The pro domain of $\beta$ secretase does not confer strict zymogen-like properties but does assist proper folding of the protease domain. J Biol Chem 2001;276: 10366-10373.

5 Luo Y, Bolon B, Kahn S, Bennett BD, BabuKhan S, Denis P, Fan W, Kha H, Zhang J, Gong Y, Martin L, Louis JC, Yan Q, Richards WG, Citron M, Vassar R: Mice deficient in BACE1, the Alzheimer's $\beta$-secretase, have normal phenotype and abolished $\beta$-amyloid generation. Nat Neurosci 2001;4:231-232.

6 Willem M, Garratt AN, Novak B, Citron M, Kaufmann S, Rittger A, DeStrooper B, Saftig P, Birchmeier C, Haass C: Control of peripheral nerve myelination by the $\beta$-secretase BACE1. Science 2006;314:664-666.

7 Beher D, Graham SL: Protease inhibitors as potential disease-modifying therapeutics for Alzheimer's disease. Expert Opin Investig Drugs 2005;14:1385-1409.
8 Scholefield Z, Yates EA, Wayne G, Amour A, McDowell W, Turnbull JE: Heparan sulfate regulates amyloid precursor protein processing by BACE1, the Alzheimer's $\beta$-secretase. J Cell Biol 2003;163:97-107.

9 Small DH, Mok SS, Williamson TG, Nurcombe V: Role of proteoglycans in neural development, regeneration, and the aging brain. J Neurochem 1996;67:889-899.

10 Beckman M, Holsinger RM, Small DH: Heparin activates $\beta$-secretase (BACE1) of Alzheimer's disease and increases autocatalysis of the enzyme. Biochemistry 2006;45:67036714.

11 Esko JD, Selleck SB: Order out of chaos: assembly of ligand binding sites in heparan sulfate. Annu Rev Biochem 2002;71:435471.

12 Benjannet S, Elagoz A, Wickham L, Mamarbachi M, Munzer JS, Basak A, Lazure C, Cromlish JA, Sisodia S, Checler F, Chretien $\mathrm{M}$, Seidah NG: Post-translational processing of $\beta$-secretase ( $\beta$-amyloid-converting enzyme) and its ectodomain shedding. The pro- and transmembrane/cytosolic domains affect its cellular activity and amyloid- $\beta$ production. J Biol Chem 2001;276:1087910887.

13 Huse JT, Liu K, Pijak DS, Carlin D, Lee VM, Doms RW: $\beta$-Secretase processing in the trans-Golgi network preferentially generates truncated amyloid species that accumulate in Alzheimer's disease brain. J Biol Chem 2002;277:16278-16284.
14 Leveugle B, Ding W, Durkin JT, Mistretta S, Eisle J, Matic M, Siman R, Greenberg BD, Fillit HM: Heparin promotes $\beta$-secretase cleavage of the Alzheimer's amyloid precursor protein. Neurochem Int 1997;30:543-548.

15 Snow AD, Wight TN, Nochlin D, Koike Y, Kimata K, DeArmond SJ, Prusiner SB: Immunolocalization of heparan sulfate proteoglycans to the prion protein amyloid plaques of Gerstmann-Straussler syndrome, Creutzfeldt-Jakob disease and scrapie. Lab Invest 1990;63:601-611.

16 Watson DJ, Lander AD, Selkoe DJ: Heparinbinding properties of the amyloidogenic peptides $A \beta$ and amylin. Dependence on aggregation state and inhibition by Congo red. J Biol Chem 1997;272:31617-31624.

17 Hiebert LM: Oral heparins. Clin Lab 2002; 48:111-116.

18 Lasker SE: Low molecular weight heparinlike preparations with oral activity. Semin Thromb Hemost 1985;11:37-39.

19 Leveugle B, Ding W, Laurence F, Dehouck MP, Scanameo A, Cecchelli R, Fillit H: Heparin oligosaccharides that pass the bloodbrain barrier inhibit $\beta$-amyloid precursor protein secretion and heparin binding to $\beta$ amyloid peptide. J Neurochem 1998;70:736744 .

20 Bergamaschini L, Rossi E, Storini C, Pizzimenti S, Distaso M, Perego C, De Luigi A, Vergani C, De Simoni MG: Peripheral treatment with enoxaparin, a low molecular weight heparin, reduces plaques and $\beta$-amyloid accumulation in a mouse model of Alzheimer's disease. J Neurosci 2004;24: 4181-4186. 